\title{
A Study of Primary School Teachers' and Turkish Language Teachers' Anxiety about Tablet PC Assisted Teaching
}

\author{
Ergün Öztürk ${ }^{1}$ \\ ${ }^{1}$ Faculty of Education, Erciyes University, Kayseri, Turkey \\ Correspondence: Ergün Öztürk, Faculty of Education, Erciyes University, 38039, Kayseri, Turkey. Tel: \\ 90-352-207-6666. E-mail: ergunozturk@erciyes.edu.tr
}

Received: December 8, 2017

Accepted: March 2, 2018

Online Published: May 29, 2018

doi:10.5539/ies.v11n6p66

URL: https://doi.org/10.5539/ies.v11n6p66

\begin{abstract}
Many educational institutions use a number of technologies in classrooms to promote the effectiveness of learning activities. In recent years, tablet PCs have become the primary of these technologies. Tablet PCs in particular play an important role in increasing the effectiveness and efficiency of the process of learning and teaching. In order to reveal this effect of tablet PCs on learning-teaching and to ensure that tablet PCs are used effectively by teachers, development of favorable attitudes by teachers towards computers and elimination of anxiety about using these devices are of utmost importance. The purpose of this study is to determine primary school and Turkish teachers' anxiety level about using tablet PCs in the process of learning and teaching. To this end, the anxiety scale for tablet PC assisted teaching developed by the researcher was administrated to the teachers. In order to determine the teachers' anxiety level about using tablet PC in teaching, cross-sectional survey technique was used in the research. According to the results of the research, Turkish teachers' anxiety level about teaching with tablet PC was found to be higher than that of primary school teachers. Also, in both branches of teaching, females have higher anxiety level about teaching with tablet PC than males. The findings of the research suggest that teachers should be provided with adequate training in using tablet PCs and integration of tablet PCs into educational activities, and that the technical infrastructure should be arranged accordingly.
\end{abstract}

Keywords: primary school teacher, Turkish teacher, tablet PC, anxiety

\section{Introduction}

When it is considered that today's children are quite good at technology, it is very important to increase the use of technology in all areas. A primary one of these areas should be education. Thus, both technological literacy can be increased and it is possible to train technology experts through education. Moreover, today information and communication technologies are very efficient tools utilized in educating children and adults both in and out of the school (Horzum, Öztürk, Bektaş, Güngören, \& Çakır, 2014). Recently, these devices which are considered to be quite important have started to be used in education in Turkey as well, and they have become rather popular among students and teachers. Movement of Enhancing Opportunities and Improving Technology (FATIH) is the best and single example of the practice of tablet PC assisted teaching.

In some studies which were examined, it was observed that education supported by technology provides students with a number of benefits and increases their understanding skills as well (Renshaw \& Taylor 2000). In a study conducted by Renshaw and Taylor, it was found that information technologies assisted teaching practices increased the students' high-level thinking skills and contributed to their understanding skills as well as improved their academic achievement. These studies reveal that audial-visual technologies addressing multiple senses should be incorporated in the educational system. For example, with practices of transition to digital textbooks as of 2012 in the United States of America, tablet PC assisted education has begun to speed up (Toppo, 2012). In this connection, it was decided with the new law that only the digital textbook must be used at K-12 (primary and high schools) schools in Florida, USA in the 2015-2016 school year (Ni, 2013; Toppo, 2012).

The fact that tablet PCs may contribute to the learning-teaching environment for students and teachers has been revealed in various studies. According to Smith (2016), teachers decide what knowledge is important and what learning opportunities must be developed. Thus, tablet PC education can be regarded as significant learning and teaching opportunities for both learners and teachers. With tablet PC education, teachers spend less time in 
creating the content of a lesson, which creates a considerable amount of time for both students and the teacher. In this way, tablet PC education ensures that teachers and students interact more in the classroom tasks and it allows a new kind of classroom interaction called a network of learning (Enriquez, 2010). Feedback can be offered to students through tablet software. In such a medium of learning, students can encounter with positive situations that influence their self-efficacy, self-control and satisfaction favorably. Robertson (2015) have stated that students' motivation increases when they use tablet PCs in classroom settings. Also, tablet PCs allow teachers to combine the best features of blackboard and multimedia narration techniques without encountering any problems (Frolik \& Zurn, 2004). Thus, in classroom environments, tablet PCs could replace the board as a presentation tool (Mock, 2004). Moreover, tablet PC can function as a "smart board" in face-to-face education.

In addition to all these positive features, it is seen that several problems about the use of tablet PCs arise as in every technology used for educational purposes. Some of these problems can be summarized as follows: problems experienced in terms of learning, teaching and motivation and problems experienced or likely to be experienced in terms of health (Rosenfield, 2011; Yan, Hu, Chen \& Lu, 2008).

While rapid developments which occur in information and communication technologies lead to changes in our daily lives, in the studies conducted, it is stated that first the use and adaptation of these technologies cause anxiety (Sugar, Crawley, \& Fine, 2004; Savage, 2000; Whetstone \& Carr, 2001). With developments in ICT, teachers may encounter problems such as anxiety when they use electronic tools to support learning (Cai, Fan, \& $\mathrm{Du}, 2017)$. ICT anxiety is a negative emotional response resulting from the fear that the use of technology may have a negative effect (MacCallum \& Jeffrey, 2014). In a study conducted by Chiu and Churchill (2016), teachers' beliefs, attitudes, and anxieties about mobile device teaching were investigated. They concluded that beliefs, attitudes and anxieties affected the acceptance, adoption, and integration of mobile devices into teaching. Also, they found that there was no significant difference in teachers' attitudes towards mobile devices in teaching, but that teachers' anxieties increased significantly. Therefore, teachers' anxiety about the use of tablet PCs stem from the fact that teachers do not know exactly how to use tablet PCs in the process of learning-teaching. The fact that tablet PCs are beneficial, useful and they are easy to use is supposed to be accepted by teachers, which will eliminate the fact that teachers suffer from anxiety in teaching.

Although many benefits of educational technologies have been documented by various researchers (Baek, Jung, $\&$ Kim, 2008), one reason that educational technologies are reluctantly used in the classroom was found to be teachers' anxiety towards the use of educational technologies (Gürcan, 2003; Myers \& Halpin, 2002). Teachers with high anxiety level are generally afraid to use or be asked to use technology in their classes. They are afraid to be confronted with technology, and thus, they may prefer not to teach by using technology and have a negatively affected learning stamina (Myers \& Halpin, 2002).

When the above review of literature on tablet PCs is considered, teachers' anxiety about tablet PC assisted teaching arises as a problem. Thus, the aim of the research is to determine the anxiety level of primary school and Turkish teachers about tablet PC assisted teaching. To this end, the answers of the following research questions will be sought:

Is there a difference between the anxiety level of primary school and Turkish teachers about tablet PC assisted teaching?

Does teachers' anxiety level about tablet PC assisted teaching vary by their gender?

\section{Method}

\subsection{Research Model}

Cross-sectional survey technique was used in the research. Cross-sectional survey technique is a research model which aims to determine whether variables differ according to other variables and which are measured only once (Fraenkel \& Wallen, 2006).

\subsection{Population and Sample}

The sample for this study was determined by convenience sampling in which the participants were selected on the basis of willingness (Creswell, 2012). The sample of the research is composed of primary school and Turkish teachers serving at schools in Sakarya. There are 80 females and 88 males in the sample.

\subsection{Data Collection Instrument}

As the data collecting instrument, the anxiety scale for tablet PC assisted teaching developed by the researcher was used. While the scale was being developed, related studies and scales in the literature (Meuter, Ostrom, Bitner, \& Roundtree, 2003; Chan \& Lee, 2005; Pierce, 2009; Saadé \& Kira, 2007; El-Gayar \& Moran,2006; 
Barbeite \& Weiss, 2004; López-Bonilla, \& López-Bonilla, 2012) were examined. Firstly, the scales were translated into Turkish by consulting foreign language experts. Following this, an item pool of 35 items was created in accordance with the study. In order to ensure the content and face validity of the scale, experts to be consulted were determined. These items went through a pre-selection by consulting two experts and they were reduced to 14 items. Eleven experts were consulted about whether this 14-item scale form satisfactorily measures tablet PC anxiety level. Two of these experts are from the department of educational sciences, two are from the department of primary school education, six are from the department of computer and teaching technologies and one is from the department of Turkish teaching. The form was presented to 20 primary school teachers and 18 Turkish teachers in order to obtain feedback about the content and language of the form. As a result of the feedback gathered from all the experts, necessary corrections were made in form and it was finally reduced to 9 items. Thus the scale was finalized. The scale is made up of 5 Likert type.

\subsection{Exploratory Factor Analysis}

The exploratory factor analysis was performed on the data obtained from the scale for construct validity. In the determination of the items to be included in the scale in the exploratory factor analysis, it was noted that eigenvalues of the items are 1 , loading values of the items are at least .30, the items are included only in one factor and there is at least a difference of .10 between the items contained in two factors. First, Kaiser-Mayer-Olkin (KMO) test was conducted, which tests the adequacy of the sample in order for this analysis to be performed. KMO value was found to be .909 . According to Field (2009), it was concluded that factor analysis could be performed on such data for this value is over .80. Second, since Bartlett's Sphericity test was conducted $(\chi 2=1183,852, \mathrm{p}=.000)$ and the data obtained showed significant difference, it was established that performing factor analysis was suitable (Field, 2009). As a result of factorial validity studies, the scale was found to have a one-factor structure.

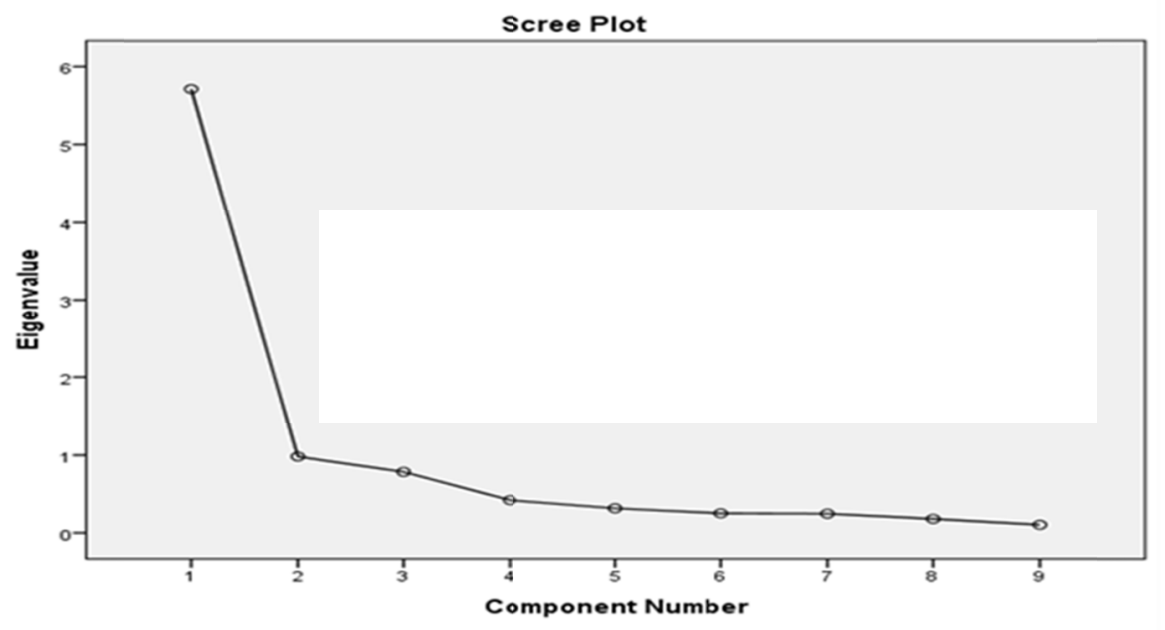

Figure 1. Scree-plot graphic factor structure

As a result of factor analysis whose eigenvalue was assigned 1 , the scale is made up of one factor as is seen in the scree-plot graphic. When the scree-plot graphic is examined, a one-factor structure has been preferred for the scale because the items in the scale have approximate values. The results of exploratory factor analysis are given in Table 1. 
Table 1. Exploratory factor analysis results of anxiety scale for tablet PC assisted teaching

\begin{tabular}{|c|c|c|c|}
\hline No & Item & $\begin{array}{c}\text { Common } \\
\text { Factor } \\
\text { Variance }\end{array}$ & $\begin{array}{c}\text { Factor } \\
\text { Load } \\
\text { Values } \\
\end{array}$ \\
\hline 1 & I am worried about thinking of using tablet PC. & .437 & .548 \\
\hline 2 & I am worried about thinking that students will use tablet PC. & .515 & .718 \\
\hline 3 & I am worried about students using necessary software for tablet PC. & .634 & .796 \\
\hline 4 & I am always worried when students use tablet PC. & .778 & .882 \\
\hline 5 & I am always worried that students can make mistakes when they use tablet PC. & .840 & .917 \\
\hline 6 & $\begin{array}{l}\text { I am worried that students can perform a wrong operation and could break the software system when } \\
\text { they use tablet PC. }\end{array}$ & .778 & .882 \\
\hline 7 & I am worried when students encounter a problem when they use tablet PC. & .765 & .875 \\
\hline 8 & I am worried about students asking questions when they use tablet PC. & .660 & .813 \\
\hline 9 & I am worried about the idea of having students use tablet PC. & .710 & .842 \\
\hline & e Accounted for $\%$ Total $=63.53$ & & \\
\hline
\end{tabular}

When Table 1 is examined, the anxiety scale for tablet PC assisted teaching has a one-factor and 9-item structure. As a result of the analysis, it is seen that total eigenvalue of the scale is 5.71 , the total variance amount it explains is $63.52 \%$, and the factor load values of the items vary between .54 and .91. Cronbach's Alpha internal consistency coefficients were calculated for the reliability of the scale. For the whole scale, Cronbach's Alpha value was found to be .90 . The scale is made up of one factor.

\subsection{Analysis of data}

SPSS software package version 13.0 was utilized for the statistical analysis of the data. Independent Samples t-test was applied to test whether there is a difference between primary school and Turkish teachers' anxiety level for tablet PC assisted teaching in the process of learning-teaching according to their branches and gender.

\section{Findings}

The participant teachers' anxiety level about tablet PC assisted teaching was examined according to their branches. T-test was conducted to see whether there is a difference between primary school and Turkish teachers' anxiety level about tablet PC assisted teaching. Descriptive results of the analysis are given in Table 2.

Table 2. The t-test result of whether there is a difference between primary school and Turkish teachers' anxiety level about tablet PC assisted teaching

\begin{tabular}{lllllll}
\hline Branch & $\mathrm{N}$ & $\bar{x}$ & $\mathrm{SS}$ & $\mathrm{Sd}$ & $\mathrm{t}$ & $\mathrm{P}$ \\
\hline Primary School Teachers & 145 & 21.79 & 7.097 & 167 & $-2,149$ & $.033^{*}$ \\
Turkish Teachers & 24 & 25.17 & 7.287 & & & \\
\hline
\end{tabular}

When Table 2 is examined, a statistically significant difference $(\mathrm{t}=-2,149 \mathrm{p}<.05)$ was found between primary school and Turkish teachers' anxiety level about tablet PC assisted teaching. The anxiety level of Turkish teachers about tablet PC assisted teaching $(X=25.17)$ was found to be higher than that of primary school teachers $(\mathrm{X}=21.71)$. The t-test result of teachers' anxiety level about tablet PC assisted teaching according to their gender is presented in Table 3.

Table 3. The t-test result of whether there is a difference between primary school and Turkish teachers' anxiety level about tablet PC assisted teaching according to their gender

\begin{tabular}{ccccccc}
\hline Gender & $\mathrm{N}$ & $\bar{x}$ & $\mathrm{SS}$ & $\mathrm{Sd}$ & $\mathrm{t}$ & $\mathrm{p}$ \\
\hline Female & 80 & 23.71 & 7.046 & & & \\
Male & 88 & 20.92 & 7.149 & 166 & 2.546 & $.012^{*}$ \\
\hline
\end{tabular}

When Table 3 is examined, a statistically significant difference $(\mathrm{t}=2.546, \mathrm{p}<.05)$ was found between female and male teachers' anxiety level about tablet PC assisted teaching. The anxiety level of female teachers about tablet PC assisted teaching $(X=23.71)$ is higher than that of male teachers $(X=20.92)$. 


\section{Conclusion, Discussion, and Suggestions}

The goal of the research is to determine the anxiety level of primary school and Turkish teachers about tablet PC assisted teaching during learning-teaching. For this purpose, in the research first of all, the "Anxiety Scale for Tablet PC Assisted Teaching" was developed. Second, primary school and Turkish teachers' anxiety level about tablet PC assisted teaching was examined by using the data obtained. Finally, whether the teachers' anxiety level about tablet PC assisted teaching differs according to their genders was investigated. The following findings were obtained based on the data of the research.

Turkish teachers are more anxious than primary school teachers about tablet PC assisted teaching. In a study conducted by Çiftçi, Taşkaya, and Alemdar (2013) on primary school teachers' opinions on FATİH project, it was revealed that the teachers' biggest anxiety $(69 \%)$ was about tablet PCs in the implementation process of the project although few (9\%) of the teachers reported that they were not anxious about the implementation of the project. The teachers reported that they were anxious due to reasons such as the use, breakdown and breaking of tablet PCs. Similarly, teachers are afraid of losing control over the classroom due to tablet computers because they think that tablet computers are attractive for students to surf the social networking sites and play games. Teachers are confronted with difficulties in transitioning to a role in which they have less control than the central role in the class. In other words, findings have indicated that teachers have a more conservative role in the implementation of innovative technologies (Montrieux, Vanderlinde, Schellens, \& De Marez, 2015). From this finding, it can be concluded that losing the control of the classroom is another factor which accounts for teachers' anxiety about tablet PC assisted teaching. In connection with this, Moats (2015) draws attention to the fact that incorporating tablet technology into the learning process increases complexity in the classroom, which brings about additional challenges and concerns in the classroom management. These difficulties and concerns can result in the teachers' rejection of technology. Lack of sufficient infrastructure, regional differences and rushing on in-service practices were also reported as other reasons that the teachers were anxious about.

In a study conducted within the scope of FATIH project by Dursun, Kuzu, Kurt, Güllüpınar, and Gültekin (2013), it was voiced that generally senior and older teachers have anxiety about and unfavorable attitudes towards the technologies accompanying the FATIH project. Also, Kaya and Koçak-Usluer (2011) mention similar findings on teachers' level of anxiety about tablet PC assisted teaching in their research. In another study conducted by Chui and Churchill (2016), it is reported that teachers acquired the knowledge and skills to use mobile devices in their classrooms; however, not all teachers could free themselves of the anxiety of using the new technology. Considering the findings of the above mentioned studies, it can safely be said that these findings are in parallel with the findings of the present research.

In the present research, female teachers' anxiety level about tablet PC assisted teaching was found to be higher than that of male teachers. Within this scope, in a study conducted by Pierce (2009) it was established that female teachers' anxiety was higher than that of male teachers'. In other studies by Durndell and Haag (2002), Abdelhamit (2002), Schottenbauer (2004), Todman (2000) it was found that female participants had more anxiety towards computers than male participants. It is seen that there exists an overlap between the results of the above mentioned studies and the findings of the present research.

In the light of these results and discussions of the present study, teachers should be provided with adequate training on using tablet PC and its integration into their teaching, and technical infrastructure should be arranged accordingly. Training to be offered to teachers on tablet PC assisted teaching may relieve their anxiety level and as teachers' anxiety is lowered with successful practices, it could be possible that teachers' beliefs, attitudes and anxiety about tablet PC assisted teaching will be favorably affected.

\section{References}

Abdelhamid, I. S. (2002). Attitudes towards Computer: A Study of Gender Differences and other Variables. Journal of the Social Sciences, 30(2), 285-316.

Baek, Y., Jung, J., \& Kim, B. (2008). What makes teachers use technology in the classroom? Exploring the factors affecting facilitation of technology with a Korean sample. Computers \& Education, 50, 224-234. https://doi.org/10.1016/j.compedu.2006.05.002

Barbeite, F. G., \& Weiss, E. M. (2004). Computer self-efficacy and anxiety scales for an Internet sample: testing measurement equivalence of existing measures and development of new scales. Computers in Human Behavior, 20(1), 1-15. https://doi.org/10.1016/S0747-5632(03)00049-9

Cai, Z., Fan, X., \& Du, J. (2017). Gender and attitudes toward technology use: A meta-analysis. Computers \& Education, 105, 1-13. https://doi.org/10.1016/j.compedu.2016.11.003 
Chan, A., \& Lee, M. J. (2005). An MP3 a day keeps the worries away: Exploring the use of podcasting to address preconceptions and alleviate pre-class anxiety amongst undergraduate information technology students. In D. H. R. Spennemann, \& L. Burr (Ed.), Good Practice in Practice: Proceedings of the Student Experience Conference (pp. 58-70). Wagga Wagga, NSW.

Chiu, T. K., \& Churchill, D. (2016). Adoption of mobile devices in teaching: Changes in teacher beliefs, attitudes $\begin{array}{llll}\text { and anxiety. Interactive Learning } & \text { Environments, }\end{array}$ https://doi.org/10.1080/10494820.2015.1113709

Çiftçi, S., Taşkaya, S. M., \& Alemdar, M. (2013). The Opinions of Classroom Teachers about Fatih Project. Illkögrretim Online, 12(1), 227-240.

Creswell, J. W. (2012). Educational research: Planning, conducting, and evaluating quantitative and qualitative research (4th ed.). Boston: Pearson.

Durndell, A., \& Haag, Z. (2002). Computer self efficacy, computer anxiety, attitudes towards the Internet and reported experience with the Internet, by gender, in an East European sample. Computers in human behavior, 18(5), 521-535. https://doi.org/10.1016/S0747-5632(02)00006-7

Dursun, Ö. Ö., Kuzu, A., Kurt, A. A., Güllüpınar, F., \& Gültekin, M. (2013). Okul yöneticilerinin FATİH Projesinin pilot uygulama sürecine ilişkin görüşleri. Trakya Üniversitesi Eğitim Fakültesi Dergisi, 3(1), 100-113.

Efe, H. A., Efe, R., \& Yücel, S. (2016). A Comparison of Swiss and Turkish Pre-Service Science Teachers' Attitudes, Anxiety and Self-Efficacy Regarding Educational Technology. Universal Journal of Educational Research, 4(7), 1583-1594. https://doi.org/10.13189/ujer.2016.040711

El-Gayar, O. F., \& Moran, M. (2006). College students' acceptance of tablet PCs: An application of the UTAUT model. Dakota State University, 820, 2845-2850

Enriquez, A. G. (2010). Enhancing student performance using tablet computers. College Teaching, 58, 77-84. https://doi.org/10.1080/87567550903263859

Field, A. (2009). Discovering statistics using SPSS. Sage publications.

Fraenkel, J. R., \& Wallen, N. E. (2006). How to design and evaluate research in education. New York: McGraw-Hill.

Frolik, J., \& Zurn, J. (2004) Evaluation of Tablet PCs for engineering content development and instruction. Computers in Education Journal, 15(3), 101-105

Gürcan, A. (2003). The effect of learning strategy on computer anxiety. Computers in Human Behavior, 19, 565-578. https://doi.org/10.1016/S0747-5632(03)00003-7

Horzum, M. B., Öztürk, E., Bektaş, M., Güngören, Ö. C., \& Çakır, Ö. (2014). Secondary School Students Tablet Computer Acceptance and Readiness: A Structural Equation Modelling. Education \& Science, 39(176), 81-93. https://doi.org/10.15390/EB.2014.3500

Kaya, G., \& Koçak-Usluel, Y. (2011). Öğrenme-öğretmen sürecinde BİT entegrasyonunu etkileyen faktörlere yönelik içerik analizi. Buca Eğitim Fakültesi Dergisi, 31, 48-67.

López-Bonilla, J. M., \& López-Bonilla, L. M. (2012). Validation of an information technology anxiety scale in undergraduates. British Journal of Educational Technology, 43(2), E56-E58. https://doi.org/10.1111/j.1467-8535.2011.01256.x

MacCallum, K., \& Jeffrey, L. (2014). Factors Impacting Teachers' Adoption of Mobile Learning. Journal of Information Technology Education, 13, 141-162. https://doi.org/10.28945/1970

Meuter, M. L., Ostrom, A. L., Bitner, M. J., \& Roundtree, R. (2003). The influence of technology anxiety on consumer use and experiences with self-service technologies. Journal of Business Research, 56(11), 899-906. https://doi.org/10.1016/S0148-2963(01)00276-4

Moats, J. (2015). Influences on the acceptance of innovative technologies used in learning opportunities: A theoretical perspective. In F. M. Nafukho (Ed.), Handbook of research on innovative technology integration in higher education (pp. 262-278). https://doi.org/10.4018/978-1-4666-8170-5.ch013

Mock, K. (2004). Teaching with Tablet PC's, Journal of Computing Sciences in Colleges, 20, 17-27.

Montrieux, H., Vanderlinde, R., Schellens, T., \& De Marez, L. (2015). Teaching and learning with mobile technology: A qualitative explorative study about the introduction of tablet devices in secondary education. 
PloS one, 10(12), e0144008. https://doi.org/10.1371/journal.pone.0144008

Myers, J. M., \& Halpin, R. (2002). Teachers' attitudes and use of multimedia technology in the classroom: Constructivist-based professional development training for school districts. Journal of Computing in Teacher Education, 18(4), 133-140.

Ni, K. (2013). The Epoch Times. Managing the Transition to Digital Textbooks. Retrieved from $\mathrm{http}: / /$ www.theepochtimes.com/n2/united-states/managing-the-transition-to-digital textbooks 344930.html

Pierce, T. (2009). Social anxiety and technology: Face-to-face communication versus technological communication among teens. Computers in Human Behavior, 25(6), 1367-1372. https://doi.org/10.1016/j.chb.2009.06.003

Renshaw, C. E. \& Taylor, H. A. (2000). The Educational Effectiveness of Computer-Based Instruction. Computers and Geosciences, 26(6), 677-682. https://doi.org/10.1016/S0098-3004(99)00103-X

Robertson, W. (2015). 1:1 technology and student motivation to learn (Order No. 3702630). Retrieved from ProQuest Dissertations \& Theses Full Text: The Humanities and Social Science Collection.

Rosenfield M. (2011). Computer vision syndrome: A review of ocular causes and potential treatments. Ophthalmic and Physiological Optics, 31(5), 502-515. https://doi.org/10.1111/j.1475-1313.2011.00834.x

Saadé, R. G., \& Kira, D. (2007). Mediating the impact of technology usage on perceived ease of use by anxiety. Computers \& education, 49(4), 1189-1204. https://doi.org/10.1016/j.compedu.2006.01.009

Savage, M. (2000). Class analysis and social transformation. Buckingham: Open University Press.

Schottenbauer, M. A., Rodriguez, B. F., Glass, C. R., \& Arnkoff, D. B. (2004). Computers, anxiety, and gender: an analysis of reactions to the Y2K computer problem. Computers in Human Behavior, 20(1), 67-83. https://doi.org/10.1016/S0747-5632(03)00044-X

Sugar, W., Crawley, F., \& Fine, B. (2004). Examining teachers' decisions to adopt new technology. Journal of Educational Technology and Society, 7(4), 201-213.

Todman, J. (2000). Gender differences in computer anxiety among university entrants since 1992. Computers \& Education, 34(1), 27-35. https://doi.org/10.1016/S0360-1315(99)00036-6

Toppo, G. (2012). USA TODAY. Obama wants schools to speed digital transition. Retrieved from http:/usatoday30.usatoday.com/news/education/story/2012-0131/schoolsetextbooks/52907492/1

Whetstone, L., \& Carr-Chellman, A. A. (2001). Preparing preservice teachers to use technology: Survey results. TechTrends, 45(4), 11-17. https://doi.org/10.1007/BF02784820

Yan, Z., Hu, L, Chen, H., \& Lu, F. (2008). Computer Vision Syndrome (CVS): A widely spreading but largely unknown epidemic among computer users. Computers in Human Behavior, 24(5), 2026-2042. https://doi.org/10.1016/j.chb.2007.09.004

\section{Copyrights}

Copyright for this article is retained by the author(s), with first publication rights granted to the journal.

This is an open-access article distributed under the terms and conditions of the Creative Commons Attribution license (http://creativecommons.org/licenses/by/4.0/). 